\title{
MAIN IDEA MEMORY STORAGE AS THE WAY TO TEACH READING COMPREHENSION FOR INDONESIAN EFL LEARNER
}

\author{
Doni Pestalozy \\ STKIP PGRI Lubuklinggau \\ Donipestalozid@yahoo.com.id
}

\begin{abstract}
English is international language that used to communicate between people in the world with different language background. In Indonesia, English as foreign language that taught in the school, so all of Indonesian students learn English as the main subject lesson in the school. In learning process there are lot of difficulties that faced by students, one of them is reading, reading is process gaining the meaning in the text that conveyed by author, students must understand the meaning of the text both of lexical and phrase, so main idea memory storage as the best technique in teaching English $h$ for the students
\end{abstract}

Keyword: Teaching, Main Idea Memory Storage, Reading Comprehension

\section{INTRODUCTION}

People use language as a communication. Without language, people cannot do the communication. Therefore, language makes people can deliver what they think. People can communicate by using their languages in a broader context. One of them is English which is used as the international language.

English is an international language. It is used for communication among the people in the world. According to Mckey (2001:12), English is an international language. It means that English is used both in a global senses for international communication between countries and in a local sense as a language of wider communication within multilingual societies. English is as the first language (L1) means that English is used for both formal and informal forum. English is as the second language (L2) means that English can be used in either formal or informal. English is as the foreign language (EFL) means that English is used only for formal 
situation such as meeting, seminars or schools (Saville, 2006:2-4). In Indonesia, English is a foreign language, which is taught to the students in elementary up to the university level (Pratama, 2011:1). It means that English is important to be mastered because by mastering English, the people in the world can communicate each other. There are four language skills. They are reading, speaking, listening, and writing. According to Santos (2001:21-35), those four language skills can be describes as follow: Listening is a receptive skill. It means that in listening involves responding to language rather than producing. Listening involves making sense of the meaningful (having meaning) sounds of language. Speaking is a productive skill, like writing. It involves using speech to express meaning to other people. Reading is a receptive skill, like listening. It means that involves responding to text, rather than producing it, and writing is a productive skill. It involves producing language than receiving, it means that forming letters and words and join these together to make words, sentences or series of sentences that link together to communicate that written words. Four language skills are related each other. Therefore, the students should master four language skills to master English well.

Among the four skills, reading takes place as an important role in learning English, besides listening, speaking, and writing. Reading as a field of teaching is consideration as one of the important areas of teaching. It is one of the important academic skills. It is also a major pillar upon which teaching and learning process is built. The reading ability plays a central role in teaching and learning success at all education states (Addison, 1996:23). It is because most of the materials of teaching and learning are in written from. It means that the students need to improve their reading skills in order to understand the teaching and learning materials. The students will be on road to academic failure, if they could not read.

The goal to any reading activity is to understand what is read. It means that everyone is expended to learn to read because being able to read is essential in human's life. By reading, people can understand the information sent or read from the 
printed pages, such as internet, newspaper, magazine, journal, articles and various types of report.

As every language has its own system, the system is different from Indonesian language. It is possible that the Indonesian learners have difficulties in learning English. One of the problems faced by the Indonesian students are related to reading comprehension. Hayati (2001:1) judges that Indonesian students can only read without being able to correlate the reading they have just read with the knowledge they have. In primary school, the students do not interested to read a books. Many students only read without knowing about the content of text. Teaching and learning activities will be concentrated on reading. This statement tells them how important the reading comprehension is.

Reading comprehension as the process of simultaneously extracting and constructing meaning trough intraction and involvement with written language (Snow, 2001:16). People use the word extracting and constructing to emphasize both the importance and the insufficiency of the text as a determinant of reading comprehension. In other words reading comprehension is process when the reader interact the knowledge with the language in understanding the writer massage in reading passage.

According to Langan (2010:62) Identifying the main idea of written selection is one of the most important comprehension skills. Sometimes the main idea is easily recognized and other times it can only be inferred. Reading will be pointless for students' unless students' can pull the main ideas from the text in order to get the writer's message. In any written passage there are relatively few main ideas. Each idea may be supported by introductory remarks, related details, and illustrations. The students must trip away these excess words and sentences and focus on the main idea.

In order to make the teaching and learning process in reading comprehension easier, the writer needs ways. One of the ways is through Main Idea Memory Storage because the writer thought that using Main Idea Memory Storage in learning and 
teaching English process, made the students understand easily because Main Idea Memory Storage usually use text books or other material.

There are some reasons why this topic was chosen. Firstly, reading is very important to the students and one of the components of English taught at school. Secondly, there are some strategies can be used to improve reading ability, besides finding the main ideas of reading text.

Teaching can be defined as the action of a person imparting skill or knowledge or giving instruction; the job of a person who teaches. Teaching is an attempt to assist students in acquiring or changing some skill, knowledge, ideal, attitude, or appreciation (Moore, 2005:5).

According to Brown (in Saleh 1997:18), teaching is guiding and facilitating learning, enabling the students to learn, setting conditions for learning. Teaching is an interactive process between the teacher and students and among students themselves. The teachers not only give the students knowledge but also the teacher must use media in learning like picture,instrument, and etc. The students can accept learning better and more easy to understanding. In other words, teaching is not explaining everything by an all knowing teacher, but asking probing quastion, and giving the students time to think and respond.

Teaching can be an exciting and refreshing interval in the day for students and teachers. There are so many possible ways of stimulating communicative interaction (Gebhard, 2000:49). It means that the teaching activity is usually done interestingly when the strategy can motivate the students to learn.

Based on the explanation above, it can be concluded that teaching is the process to help students develop knowledge, skill and attitude and used to increase motivation and attention of students in learning English. The teaching in this study is the activity to guide, facilitate, and enable the students to understand main idea through Main idea memory storage. 


\section{The Concept of Reading}

Reading is one of the most dominant skills in learning any subjects, because the ability to read is not only performance to pronounce the passage, but also the understanding of message from a passage or text. According to Saleh (1997:41), reading is the skill that may be often used and retained the longest. It concerns not only assigning English sounds to the written words but also the understanding of what is written.

From the explanation above, reading is not only seeing and pronouncing the words correctly but also the students should be able to get the main idea of reading texts so that it can enlarge the student's knowledge. Therefore, reading is one skill that can help the students to acquire the ideas whenever the students want to speak and write. Reading also can make the students to be a smart person, because by reading many good articles in the internet make the students feel as if they have gone around all over the world.

\section{The Concept of Reading Comprehension}

Reading comprehension is a highly interactive process that takes place between a reader and a text (Crown, 2006:1). Reading comprehension is highly interactive process on general knowledge of reading as well as on experience of the world. This in turn enables us to increase our knowledge in these areas.

According to Snow (2001:16), reading comprehension as the process of simultaneously extracting and constructing meaning trough intraction and involvement with written language. People use the word extracting and constructing to emphasize both the importance and the insufficiency of the text as a detreminant of reading comprehension.

According to Grellet (1998:3) reading comprehension understands a written text means extracting the required information from is as efficiently as possible.

In other words reading comprehension is process when the reader interact the knowledge with the language in understanding the writer massage in reading passage. 


\section{The Concept of Main Idea Memory Storage}

According to Zwiers (2004:43), Main idea memory storage is a visual and kinesthetic implication of the active thinking people use to comprehend. It is technique that help the students to get the main ideas easily and improve their reading comprehension skill. It gives students practice in keeping one "mental hand" on the main idea and the other "mental hand" on the summary chuncks of information that relate to the main idea.

According to Buus (2010:55) Main Idea Memory Storage is Memory has three main steps to memory storage: sensory memory storage, short-term memory storage, and long-term memory storage (Turkington \& Harris, 2001). It is desirable for students to get major concepts into long-term memory and back out when needed. This process includes the steps of encoding, storage, retrieval, and reporting. Many factors can influence these steps. Teaching memory strategies could help improve a student's memory ability. In this study, keeping a reading response journal was the strategy used to reach this goal and subsequently to improve reading comprehension.

Short-term memory storage is the temporary storage of information while it is being processed and that important information must then be pushed on to long term memory storage. The short-term memory has also been referred to as the working memory. It is here as a "mental work space" that people sort and encode information before adding it to long-term memory, or we pull information from longterm memory to reprocess it. Levine (2002) says that long-term memory is "the warehouse for more or less permanent knowledge,". It is in the long-term memory that storage involving associations with words or meaning occurs.

From the explanation above, the writer concludes that Main Idea Memory Stoage is technique to create comprehension habit of the learners in organizing text information by sculpting the main idea at adressing the memory issues that are seen daily in the classroom. To take this idea, the memory process can be looked at as 
having four parts, encoding, storage, retrieval, and reporting. The encoding would be to attend to and interpret the information. The storage would be the holding of information.

\section{The Procedure of Main Idea Memory Storage}

According to Zwiers (2004:43), the procedure of main idea storage:

a. Choose a narrative or expository text that is challenging to the students

b. Ask them to find the main idea of the text, then write the main idea on a sticky note (use clear ones if students are working on a overhead projector) and place it in the top box of the main idea memory storage form. Then explain to students that they will modify the main idea while they read.

c. Ask them to read aloud from the text and stop at an appropriate point to summarize in a summary note (use a different color of sticky note than the main note, ideally) and place it on one of the six boxes under the main idea note. Discuss with students whether the summary requires students to change their main idea note or not. If so, write a new main idea note and replace the old one. The old one can go down on the lower right stack. Repeat this step in six times.

d. When their six summary boxes are full, explain aloud to students as they shuffle them around based on importance, the upper three being more important than the lower three, and explain how they can consolidate two or more notes into one (e.g. by classifying and categorizing). As they run out of spaces in the six boxes. They can move old or less-important information to the four boxes on the lower left of the diagram.

e. As they read the text, continue to use sticky notes to modify the main idea and move around the important information found in the text.

f. When a revised main idea forms, move the former main idea to the bottom right space on the diagram.

g. Notes that hold important supporting information can be shuffled around to fill the six spots along with the most important supporting summaries. 
h. When students understand what to do, have them go through the process in pairs as they assist them.

\section{Suggestions}

From conclusion above, the writer would like to offer some suggestions to teacher of English, the students and the other researcher.

\section{To the Teacher of English}

- The teacher of English may choose one of technique such as Main Idea Memory Storage which could increase the students' reading comprehension mastery, because it is interesting technique and increase cooperation among the students.

- Be more very creative in choosing the suitable method of the process of English teaching and learning, especially for teaching yes-no question.

\section{To the Students}

In order to make the students get a better score, they are suggested to do the following suggestion:

- Be more active in learning Main Idea Memory Storage, especially in comprehending the text.

- Retain as many as possible new text every day so that they will not get difficulties in learning English.

- Enrich their reading comprehension skill through learning new text by using Main Idea Memory Storage.

\section{To the Other Researchers}

Other researchers are expected to reuse the Main Idea Memory Storage in teaching reading. In addition by researching Main Idea Memory Storage toward reading comprehension then the effectiveness of Main Idea Memory Storage was more eligible. 


\section{REFERENCES}

Addison, J. 1996. Definition of Reading. http://www.siu.edu/ arc/chapter3. Html-14k. Accessed on March 7, 2011.

Alexa. 2012. 40 Contoh Terbaik Narrative Text Fable Bahasa Inggris. Retrieved on November 29,2014. http://englishstory12.blogspot.com/2012/11/kumpulannarrative-fable-terlengkap.html

Afriani, R. 2010. Teaching Reading Comprehension using Individualized Reading to the Eighth Grade Students of SMP Negeri 1 Indralaya. Palembang: University of PGRI Palembang.

Arifin.N. 2000. Teaching Reading Comprehension by using Matrix to the Eight Grade Student of SMP Negeri 2 Lubuklinggau. Unpublished Undergraduate Thesis. Lubuklinggau: Institute of Teacher Training and Education Teacher Association of republic of Indonesia (STKIP-PGRI).

Arikunto, S. 2010. Prosedur penelitian. Jakarta: PT. Rineka Cipta.

Brown, H.D. 1987. Principle of Language Learning and Teaching. San Fransisco: Prentice. Hall, inc

Buus, Lauree M. 2006. Using Main Idea Memory Storage for Reading Comprehension. U.S.A. Unpublised: MCSI program at Black Hills State University

Cameron, L. 2001. Teaching language to young learners. Cambridge: cambridge university press.

Fraenkel, Jack R, and Wallen, Norman E. 1990. How to Design and Evaluate Research in Education. America: Mc Graw-Hill, Inc.

Gebhard, J. G. 2000. Teaching English as a foreign or Second Language. USA: The university of Michigan Press.

Grellet, F. 1983. Developing Reading Skill. Cambridge: Cambridge university press.

Hatch, E, and Hossein F. 1982.Research Design and Statistics. Los Angeles: Newburry House Publisher.

Heaton, J.B. 1989. Writing English Language Test. New york: Longman Group. 
Hengle and Heinle. 2001. Teaching English as a School Foreign Language. USA: Hengle and Heinle

Indasiswini, J. 1997. Increasing Students' comprehending by using the DRA Strategy. Unpublished Undergraduate Thesis. Indralaya: Faculty of Teaching Training and Education, Sriwijaya University.

Jeff, Z. 2004. Building Reading Comprehension Habits in Grades 6-12: Toolkit of Classroom Activities.USA:International Reading Association, Inc.

Jihad, A, and Haris, A. 2008. Evaluasi Pembelajaran. Yogyakarta: Multi Pressindo. Langan, J. 2010. Ten Steps to Advancing College Reading Skills. New Jersey. Towsend Press.

Linse. T. 2001. Improving School Effectiveness. Buckingham: Open University Press. Moon, 2000. Teaching concepts and vocabulary: Principles and strategies. [Online] http://coe.sdsu.edu/people/jmora/ConceptsTch.html. (19 Jan 2013).

Moore, K. 2005.Effective Instructional Strategies From Theory to Practise. California: Sage Publication Inc.

Paul, D. 2003. Teaching English to Children in Asia. HongKong: Person Education Asia Limited

Philip. K. 1996. Teaching English. Accessed from www.Teachingenglish.pdf retrieved on January, $21^{\text {th }}, 2013$.

Richards, J. C., J. Platt, and H. Weber.1985. Longman Dictionary of Applied Linguistics. Hong Kong: Longman Group (FE) Ltd.

Saleh, Y. 1997. Methodologyo of Tefl in the Indonesian Context Book 1. Palembang: Faculty of Teacher Training and Education, Sriwijaya University Sudrajat, and Subana. 2001. Dasar-Dasar Penelitian Ilmiah. Bandung: Pustaka Setia. Sugiono. 2001. Dasar-Dasar Penelitian Ilmiah. Bandung: Pustaka Setia.

Sundari. 2010.Teaching Reading Comprehension Through REDW(Read, Examine,Decide,Write) Strategy with Theme "The Nature" to the Eighth Grade Students At SMP Negeri 20 Palembang.Palembang: University of PGRI Palembang. 
Vaughn., Sharon., and Thompson, Linan. 2004. Research Based Method of Reading Instruction. USA: Association for Supervision and Curriculum Development.

Wardiman, A, and Jahur, Masduki B. 2008. English in Focus. Malang: PT Temprima Media Grafika.

Webster. 1990. A complete dictionary containing definitions as well as brief etymologies.

Wilson, H.W. 2005. The Language of Science, The Language of Students:Bridging the Gap with engaged Learning Vocabulary Strategies. England: Wilson Company.

Yuliawati. 2008. Teaching reading comprehension by using octagon board as teaching medium to rhe eighth grade students at mp negeri 10 palembang. Unpublished undergraduate thesis fakultas keguruan dan ilmu pendidikan, universitas sriwijaya, indralaya. 